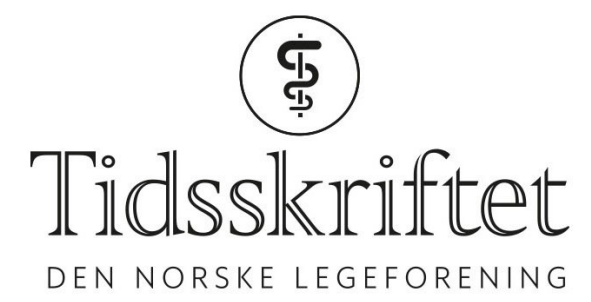

\title{
Hva sier ungdom selv om hvorfor de skader seg?
}

DEBATT

\section{LINE INDREVOLL STÄNICKE}

E-post: l.i.stanicke@psykologi.uio.no

Line Indrevoll Stänicke er psykologspesialist og ph.d.-stipendiat ved Universitetet i Oslo, Lovisenberg sykehus/Nic Waals Institutt.

Forfatteren har fylt ut ICMJE-skjemaet og oppgir følgende interessekonflikter: Institusjonen har mottatt penger fra Extrastiftelsen for helse og rehabilitering, Rådet for psykisk helse, FO4115.

Systematisk gjennomgang og syntese av kvalitative studier kaster nytt lys over årsaker til at ungdom skader seg selv.

Familie og helsepersonell strever ofte med å forstå hvorfor ungdommer skader seg og kan oppleve hjelpeløshet og overveldelse. Ungdommene på sin side kan fortelle at de ofte blir misforstått når de søker hjelp. I denne artikkelen ønsker jeg å fremheve forskningsmessig kunnskap om selvskading og spesielt hvordan erfaringsbasert kunnskap om ungdommenes perspektiv bidrar til økt forståelse. Forståelse for det som ved første øyekast bare kan virke som destruktiv atferd, er viktig for klinikere for å opprettholde empati, ønske om å hjelpe og mulighet for å tilpasse behandling.

Epidemiologiske studier har vist at selvskading kan ta ulike former, men omfatter oftest det å kutte seg, skrape, stikke hull på huden eller brenne seg (1). Det anslås at 13-17\% av ungdommer har skadet seg i løpet av livet (1). Tallene varierer avhengig av om man inkluderer selvskading med selvmordsintensjon eller ikke. Selvskade ses oftere hos jenter og de med ikke-heterofil seksuell orientering, og sammen med psykososiale risikofaktorer som å ha opplevd traume eller overgrep, selvmord i familie, mobbing, selvskade blant venner eller dårlig problemløsningsevne (2). Selvskading ses ved flere psykiske lidelser og $\emptyset$ ker risikoen for selvmord (2). Den kan ta svært ulik form og ha varierende omfang: noen skader seg et par ganger, noen i en periode, og andre fortsetter med omfattende selvskade som voksne, ofte som ledd i psykisk lidelse og personlighetsforstyrrelse.

En rekke teorier har blitt lansert for å forstå selvskading som fenomen. En teori som har blitt trukket frem som best forskningsmessig underbygd, er at selvskade virker affektregulerende, dvs. handlingen fører til en følelse av lettelse, reduserer vonde og øker gode følelser (3). Selvskading kan også ha selvstraffende funksjon (3).

Siden selvskade oftest starter i ungdomsalderen, dvs. fra 12-13 år (1), kan det være naturlig å forstå atferden utviklingspsykologisk. Ungdomstiden er forbundet med biologiske, kognitive, sosiale og emosjonelle bevegelser og endringer (4). Svingninger i følelser, impulsivitet, grenseutprøvning og risikoatferd er ikke uvanlig. I forskningslitteraturen drøftes likevel i liten grad atferden i lys av psykologiske utfordringer som økt selvfølelse, 
løsrivelse mot relasjonell gjensidighet, identitetsforming og autonomi (5).

\section{Kvalitative studier og metasynteser}

Oversiktsartikler om selvskadingens funksjon fokuserer i stor grad på voksne pasienter og ekskluderer ofte kvalitative studier basert på et lavt antall personer $(3,5)$. I epidemiologiske studier er spørreskjemaene hovedsakelig utviklet med utgangspunkt i voksne pasienter, og mange teorier utviklet om selvskade tar også utgangspunkt i forfatterens beskrivelse av voksne pasientens opplevelse (5).

Kvalitative studier gir mulighet til å fremheve og utforske ungdoms opplevelser av motiv. En metasyntese er en systematisk måte å analysere foreliggende kvalitative studier. Målet er å utvikle begreper i syntetisert form. I samarbeid med to andre forskere foretok undertegnede en analyse av 20 kvalitative studier av unges erfaring av egen selvskade (5). Primærfunn (dvs. for eksempel sitater) og sekundærfunn (dvs. forfatternes fortolkning av funnene) i de respektive artiklene ble analysert på nytt og relatert til hverandre. Analysen resulterte i fire metatemaer, hvor ungdom beskrev selvskadingen som å 1) få lettelse, 2) kontrollere vanskelige følelser, 3) forsøk på å uttrykke ikke-aksepterte følelser, og 4) forsøke å skape kontakt og dele erfaring.

\section{Selvskading som et forsøk på kommunikasjon}

Våre funn støtter tidligere forskning som har betraktet selvskade som en måte å regulere affekt på (3). Det å redusere og kontrollere følelser oppleves som essensielt ved selvskadingen. Likevel viser metasyntesen at ungdommer opplever at selvskading er nødvendig for å uttrykke følelser og frustrasjon som ikke kan vises eksplisitt, eller for å dele med andre vanskelige opplevelser som det er umulig eller ulovlig å sette ord på. For ungdommene kan det synes å være en konflikt mellom på den ene siden et grunnleggende behov for å utvikle måter å uttrykke og bearbeide erfaringer på og på den andre siden et relasjonelt behov for å få omsorg og trygghet og bli ivaretatt (5). Det kan være helt umulig å uttrykke vanskelige erfaringer direkte med ord og følelser fordi de føler at de må beskytte andre sentrale personer i livene deres. Selvskade kan derfor være et forsøk på å kommunisere viktige erfaringer til andre mennesker som betyr noe for dem.

Flere behandlingsmodeller kan være effektive hos ungdom som skader seg selv, som kognitiv terapi, dialektisk atferdsterapi og mentaliseringsbasert terapi (2), men ingen behandlingsmetode hjelper alle. Selvskade bør forstås i sammenheng med både psykisk lidelse, psykologiske utviklingstemaer og kompliserte relasjonelle forhold. Ved å hjelpe ungdommer med å utforske og utvikle alternative måter å regulere og uttrykke overveldende følelser, traumer og ensomhet på, kan vi hjelpe dem til å utvikle en tryggere identitet. Et viktig utgangspunkt er å ikke ta for gitt at vi vet hva selvskadingen handler om for den enkelte, men å undersøke hvilken mening atferden har for dem i deres liv.

LITTERATUR:

1. Swannell SV, Martin GE, Page A et al. Prevalence of nonsuicidal self-injury in nonclinical samples: systematic review, meta-analysis and meta-regression. Suicide Life Threat Behav 2014; 44: 273-303. [PubMed][CrossRef]

2. Saunders KE, Smith KA. Interventions to prevent self-harm: what does the evidence say? Evid Based Ment Health 2016; 19: 69-72. [PubMed][CrossRef]

3. Klonsky ED. The functions of deliberate self-injury: a review of the evidence. Clin Psychol Rev 2007; 27: 226-39. [PubMed][CrossRef]

4. Landmark A, Stänicke LI. Det uforståelige barnet. Om å skape sammenheng mellom indre og ytre verden. Stavanger: Hertervig forlag, 2016.

5. Stänicke LI, Haavind H, Gullestad SE. How do young people understand their own self-harm? A 
meta-synthesis of adolescents' subjective experience of self-harm. Adolesc Res Rev 2018; 3: 173-91. [CrossRef]

Publisert: 8. april 2019. Tidsskr Nor Legeforen. DOI: 10.4045/tidsskr.19.0194 Mottatt 5.3.2019, første revisjon innsendt 8.3.2019, godkjent 12.3.2019.

(C) Tidsskrift for Den norske legeforening 2020. Lastet ned fra tidsskriftet.no 